\title{
THE IMPORTANCE OF INNOVATIONS IN THE ACTIVITY OF COMMERCIAL BANKS - SELECTED PROBLEMS
}

\author{
Sylwia STACHERA-WŁODARCZYK \\ Częstochowa University of Technology, Management Department; sylwia.stachera-wlodarczyk@pcz.wz.pl, \\ ORCID: 0000-0001-7414-9113
}

\begin{abstract}
Purpose: The publication aims are to present bank innovations as one of the types of financial innovations, discuss the main directions of changes in this area, and present selected products of modern banking.
\end{abstract}

Design/methodology/approach: The implementation of the main objective adopted was possible due to the separation of the theoretical and practical parts in the article. The theoretical discussion was based on the method of analysis and criticism of the literature in the field of financial innovation. In turn, the empirical part, which is definitely the greater part of the article, was developed using simple statistical methods. The task of the adopted methods was to analyze quantitative data on the Polish mobile banking market. The article was based on information obtained from the reports of the Polish Bank Association and information available on the websites of the surveyed commercial banks. These data were used to diagnose the specifics of mobile banking in Poland.

Findings: The obtained research results showed the importance of mobile applications not only from the point of view of the commercial bank but also the client. For banks, activity in the field of using mobile applications is an important source of acquiring a potential customer. In turn, for the customer using mobile applications means easier access to banking services and products.

Originality/value: The considerations contained in the article, which are a source of information about mobile banking applications, can be enforced by both banks and their potential clients. The presented research confirmed that mobile applications currently available to customers are of decisive importance for the success and development of banks. In addition, the factor determining the maintenance of a high level of competitiveness on the mobile banking market by banks is the provision of convenient and modern methods of transaction execution.

Keywords: innovations, bank innovations, mobile payments.

Category of the paper: Research paper. 


\section{Introduction}

The ability of banks to adapt to unstable market conditions is a manifestation of their creativity and is undoubtedly determined not only by the growing importance of technology but also by trends associated with increasing globalisation. Today's banks see the need for continuous improvement of their existing products and the creation of brand new products that better and better meet the changing needs of their potential customer. Thus, in order to develop and maintain a high competitive position on the market, they must have the ability to create change. The source of these changes are financial innovations, which are characterized by a high level of modernity and competitiveness.

The aim of the publication is to present bank innovations as one of the types of financial innovations, discuss the main directions of changes in this area and present selected products of modern banking. An attempt was made to verify the hypothesis that an important determinant of banks' innovativeness is the level of customer satisfaction. For this purpose the article was divided into several sections. The first one is an introduction to the subject of the article. The second section refers to the very essence and specificity of financial innovations. The third one presents bank innovations that customers have been able to use in recent years. The fourth section describes the functions of mobile applications available on the market and the fifth section presents the Polish mobile banking market.

The considerations contained in the article lead to the conclusion that an important factor determining the banks' ability to maintain a high level of competitiveness on the mobile banking services market is the provision of convenient and modern ways of executing transactions, which is currently reflected, among others, in the development of available mobile applications.

\section{Financial innovations in banks - the essence and specificity}

Financial innovations are increasingly seen as strategic success factors for economic entities in today's economy. For the proper functioning of banks, as a specific type of enterprise operating on financial markets, they are undoubtedly of significant importance (Spoz, 2014).

Financial innovations are financial services, which are primarily related to: offering a specific group of customers a new product; activities aimed at introducing and improving new financial instruments or changes in organizational structures; introducing modern techniques and computerisation (Bakalarczyk, 2006). Thus, they cover an undetermined and heterogeneous group of financial phenomena, processes and instruments (Spoz, 2014). 
The diversity of the approach to the essence of financial innovations has caused that they have not been uniformly interpreted and no universal definition has been developed so far. In the literature they are presented both in a narrow and wide perspective. Financial innovations in a narrower sense are identified with changes taking place in financial techniques and instruments. This means that, from the point of view of a given entity, a financial innovation may be an instrument or technique already well known on the financial market. In turn, the broad approach to financial innovation concerns the financial system, thus covering new solutions related to any of the elements of the financial system, as well as changes occurring in regulations concerning their functioning (Marcinkowska, 2012; Błach, 2011, 2012).

The specific nature of mechanisms for creating and implementing financial innovations means that they are accounted for according to different classification criteria. The most important of them include: sources of innovation, factors influencing the process of creating and introducing innovations, types of innovations, innovation functions, motives for using innovations and effects of applying innovations. It should be stressed that regardless of the type of financial innovations, they are determined by certain groups of factors. Basically, they include factors of external and internal nature. Undoubtedly, external factors are among the factors that have a significant impact on the increased activity of financial institutions, including banks, in creating and implementing financial innovations. The analysis of external reasons for the introduction of financial innovations by banks leads to the identification of four basic groups of determinants, which are: the market (changes in the financial environment, globalisation and disintermediation of financial markets, increased competition between financial institutions), regulatory factors (legal regulations, standards, limits, restrictions implemented by the state), demand (changes in customer expectations), and technology (dynamic development of information and communication technologies). Among the determinants of the development of financial innovations there are also internal factors related primarily to the bank's strategy, organization and openness to change (Marcinkowska, 2012).

Therefore, financial innovations are novelties introduced in the activity of banks, which in their essence should first of all meet new needs, expectations and preferences of customers or satisfy them in a different way than before, offering additional benefits (Dolińska, 2010). Basically, there are three main factors that force banks to introduce financial innovations. These are: financial instability associated with unpredictable changes in both interest rates and exchange rates; regulations limiting the use of certain types of financial intermediation; and the development of technologies enabling the creation of new banking products and reducing unit costs (Niczyporuk \& Talecka, 2011). 


\section{Innovations in the Polish banking sector}

Financial innovations relating to the area of bank operations are referred to as banking innovations. They relate to new, hitherto unused bank operations or financial instruments. They include activities of both organizational and technical nature, consisting in the introduction of new banking products, organizational changes or new techniques and technologies (Ziemba, 2012). Banks compete with each other by offering their customers more attractive terms and conditions of contracts, more favourable interest rates on bank deposits, lower interest rates on loans, small or zero costs related to bank account maintenance. Such actions undoubtedly contribute to the growth of interest in the services of a given bank, however, apart from these factors, innovations play an important role, thanks to which the account can be serviced in a much faster, more convenient and accessible way. It should be stressed that innovations do not have to be new to the market on which a given economic entity operates, but they must be new at least to the bank itself (Kokot-Stępień, 2016).

The banking sector in Poland is modern and innovative. We are the best primarily in innovative electronic banking. The high position of innovative solutions of the Polish banking sector proves how effectively and skilfully they keep up with the pace of the change. Polish banks not only keep up with global trends, but also create them themselves, providing customers with modern solutions. Especially worth emphasizing are those solutions which bring most benefits to the customers. Table 3 presents an overview of the most interesting innovations of Polish banking that could be used in recent years.

Table 3.

Overview of the most interesting innovations of the Polish banking sector

\begin{tabular}{|c|c|}
\hline $\begin{array}{c}\text { Name of } \\
\text { innovation }\end{array}$ & Specificity of innovation \\
\hline \multicolumn{2}{|r|}{ Year 2015} \\
\hline $\begin{array}{l}\text { Card with a } \\
\text { dynamic CVC } \\
\text { code }\end{array}$ & $\begin{array}{l}\text { Ordinary payment card that has a fixed CVC code. Getin Bank was the first bank in the } \\
\text { world to introduce it. The CVC code, displayed on a tiny screen on the back of the media, } \\
\text { changes every hour, making the instrument particularly useful for online transactions, } \\
\text { when the payer is particularly vulnerable to data loss. }\end{array}$ \\
\hline $\begin{array}{l}\text { European } \\
\text { payment card }\end{array}$ & $\begin{array}{l}\text { The V Pay card, known as the European payment card, is an instrument that is recognized } \\
\text { by sales and service points and ATMs in all Eurozone countries. Its holder is treated as if } \\
\text { they had an account and card in the country concerned. In Poland, the V Pay card can be } \\
\text { ordered free of charge by Smart Bank customers setting up a Smart Konto EU. BZ WBK } \\
\text { also offered it for several years. }\end{array}$ \\
\hline $\begin{array}{l}\text { Logging in to the } \\
\text { account by voice }\end{array}$ & $\begin{array}{l}\text { People who have an account with Smart Bank and have access to the mobile application } \\
\text { can log in to the account by saying a specific command. This is not an absolute novelty. } \\
\text { In 2014, Meritum Bank created a mobile application which could manage voice } \\
\text { commands. However, the software did not allow logging into the account in this way. }\end{array}$ \\
\hline
\end{tabular}


Cont. table 3.

\begin{tabular}{|c|c|}
\hline $\begin{array}{l}\text { Multi-currency } \\
\text { debit card }\end{array}$ & $\begin{array}{l}\text { Pekao Bank introduced a multi-currency debit card. The fact that the card itself recognizes } \\
\text { the means of payment in which transaction is executed and debits the customer's } \\
\text { appropriate currency account is be considered a significant advantage. In this way, } \\
\text { customers avoid commissions for currency conversions. The customer also does not have } \\
\text { to switch the card between accounts. A multi-currency card handles payments in PLN } \\
\text { (it can be normally used to pay in Poland), USD, EUR, GBP and CHF. It also allows for } \\
\text { commission-free withdrawals from UniCredit ATMs in countries where this Italian } \\
\text { financial group operates. }\end{array}$ \\
\hline Mobile ADMs & $\begin{array}{l}\text { Idea Bank proposed a mobile ATM. The customers of this bank from the biggest towns } \\
\text { and cities can order for free through a mobile application or telephone banking at the } \\
\text { agreed place and time the arrival of the device that collects cash. A mobile cash deposit } \\
\text { machine works the same way as a regular one. After opening the car window, in which the } \\
\text { equipment is installed, the user inserts the card into the reader, enters the amount on the } \\
\text { keyboard, places the money in the tray and the machine prints the operation confirmation. } \\
\text { The transaction is posted within } 30 \text { minutes. }\end{array}$ \\
\hline \multicolumn{2}{|r|}{ Year 2016} \\
\hline $\begin{array}{l}\text { Integration of } \\
\text { Internet banking } \\
\text { and e-government }\end{array}$ & $\begin{array}{l}\text { Parents who are entitled to the 'Family } 500 \text { plus" benefit may use electronic banking to } \\
\text { submit applications. This possibility is offered free of charge by almost all universal retail } \\
\text { banks in our market. Additionally, the e-government services can be used by customers of } \\
\text { PKO BP, Bank Millennium, Alior Bank, BOS and Idea Bank and through Internet banking } \\
\text { they can verify their identity and gain access to their Social Insurance Institution (ZUS) } \\
\text { account (ZUS Electronic Services Platform). PKO BP, ING Bank Śląski and Millennium } \\
\text { Bank also enable the customers to set up a personal Trusted Profile (eGO) on the electronic } \\
\text { public administration services platform (ePUAP) from their personal account. }\end{array}$ \\
\hline $\begin{array}{l}\text { Third party } \\
\text { passenger car } \\
\text { liability } \\
\text { insurance via } \\
\text { mobile phone }\end{array}$ & $\begin{array}{l}\text { The customers of Millennium Bank, using the bank's applications, can conclude fully } \\
\text { online third party liability insurance, car insurance, Assistance, accident and glass } \\
\text { insurance offered by Ergo Hestia Group companies. In order to purchase a third party } \\
\text { liability insurance policy you need to run the software, scan with your smartphone the } \\
\text { Aztec graphic code from the vehicle registration card--* }\end{array}$ \\
\hline $\begin{array}{l}\text { Authorization of } \\
\text { card } \\
\text { transactions with } \\
\text { a fingerprint }\end{array}$ & $\begin{array}{l}\text { So far, card transactions on the Internet have been confirmed under the 3D Secure service } \\
\text { with a code sent by the bank to a mobile phone or with the PIN of the mobile application. } \\
\text { The customers of Millennium Bank using the mobile application on devices equipped with } \\
\text { biometric readers can now authorize such operations with a fingerprint. }\end{array}$ \\
\hline $\begin{array}{l}\text { Leasing for } \\
\text { kilometres }\end{array}$ & $\begin{array}{l}\text { At the end of last year, Idea Bank proposed an unusual model of vehicle leasing, in which } \\
\text { the customer, in addition to a fixed, small monthly fee, also pays the agreed rate for } \\
\text { kilometres driven. The latter is counted by the GPS system installed in the leased car or } \\
\text { agricultural machine. }\end{array}$ \\
\hline \multicolumn{2}{|r|}{ Year 2017} \\
\hline $\begin{array}{l}\text { Video verification } \\
\text { when opening a } \\
\text { personal account }\end{array}$ & $\begin{array}{l}\text { Video verification is the latest method of confirming the customer's identity by a bank } \\
\text { when remotely concluding a financial product agreement, e.g. savings and current account. } \\
\text { It was first used by Inbank, which in this way grants cash loans online. The pioneer in } \\
\text { opening personal accounts this way was Alior Bank. In the autumn, it was followed by BZ } \\
\text { WBK, and at the end of the year - Nest Bank. The solution works mainly on desktop } \\
\text { computers. For the time being, only BZ WBK enables opening a current account by video } \\
\text { verification in a mobile application. }\end{array}$ \\
\hline $\begin{array}{l}\text { Contactless cash } \\
\text { deposit machines }\end{array}$ & $\begin{array}{l}\text { The first contactless cash deposit machines were used by the customers of BGŻ BNP } \\
\text { Paribas. Compared to regular self-service devices, the difference is that the card does not } \\
\text { need to be inserted into the machine - it is enough to bring it closer to the reader. On this } \\
\text { basis, the system identifies the holder of the card and assigns the deposit to the appropriate } \\
\text { account. }\end{array}$ \\
\hline
\end{tabular}


Cont. table 3.

\begin{tabular}{|l|l|}
\hline $\begin{array}{l}\text { PIT submission } \\
\text { through a bank } \\
\text { account }\end{array}$ & $\begin{array}{l}\text { From 2017 onwards, the annual PIT of an individual may be drawn up by the competent } \\
\text { tax office. You only have to apply for it by submitting a PIT-WZ form. This form can only } \\
\text { be sent electronically, e.g. through a Trusted Profile or Internet banking. PIT-WZ } \\
\text { submission by Internet banking is confirmed by a one-time code received from the bank. } \\
\text { Such a solution is provided by, among others, PKO BP, BGZ BNP Paribas, Raiffeisen } \\
\text { Polbank and SKOK Stefczyka. Whereas the Trusted Profile can be established from the } \\
\text { transaction system level of eight banks. They include: PKO BP, Inteligo, Millennium } \\
\text { Bank, ING Bank Sląski, Pekao Bank, mBank, BZ WBK and EnveloBank. }\end{array}$ \\
\hline $\begin{array}{l}\text { Generation of } \\
\text { JPK from } \\
\text { Internet banking } \\
\text { level }\end{array}$ & $\begin{array}{l}\text { At the beginning of last year, Millennium Bank provided in Internet banking for business } \\
\text { customers (Millenet for companies) an option to automatically create and transmit } \\
\text { JPK_WB in the format required by the Ministry of Finance. }\end{array}$ \\
\hline
\end{tabular}

Note: www. bank24.blox.pl/ (29.06.2018).

The presented information shows that banks outdo each other in upgrading their products and services, making them even more attractive and modern. In addition, the introduction of financial innovations brings many benefits to the banks, which primarily contribute to a better adaptation of the banks to the ever-changing needs of customers. It increases their ability to diversify the risk of their activities and contributes to the bank's profitability. Thanks to the introduction of innovative products and services, banks are becoming leaders in terms of innovation and the number of customers acquired. The introduction of financial innovations in banks also brings a number of benefits to the environment in which they operate. They can therefore be considered as one of the most important factors contributing to the creation and maintenance of a competitive advantage on the market (Michalczuk, 2014).

The implementation of financial innovation in banks can therefore be considered as one of the more important factors contributing to the creation and maintenance of a competitive advantage in the market. However, taking into account the specific nature of their operations and the immateriality of the products they offer, building their competitive advantage is more complicated.

\section{Mobile banking applications and their functions}

Polish banks are constantly implementing advanced tools and methods to acquire new customers who expect comfortable and modern ways of carrying out transactions. Such solution is mobile payments, made entirely by mobile phones, smartphones or tablets. Initially, mobile applications were supposed to be only a supplementary channel of access to an account with a limited number of available operations. Over time, they became a competition for Internet banking. This is because mobile applications revolutionized the market with their innovation, because every owner of a mobile device can use it anywhere in the world, at any time of the day and without having a computer and sometimes even the Internet. Therefore, it is not surprising that banks started to offer their services also through such media. 
According to the ranking "The best banking mobile applications - March 2018" prepared by Bankier.pl, the best mobile applications are offered by mBank and Bank Zachodni WBK, which stand out from the competition with a wide range of available functions and services that often go beyond standard mobile banking options. The second place was taken by ING Bank Śląski, while programs offered by Pekao and PKO BP as well as Millennium Bank (Boczoń, 29.06.2018) were in third place.

What differentiates the banks in terms of available services and functionalities in mobile banking is their offer of mobile loans, mobile payments, additional services and strategic cooperation with the operator, which enables a number of business synergies and gives great potential for further functional development. Each of the banks listed has interesting solutions in its offer, which is presented in Table 4.

Table 4.

Overview of functions of selected mobile applications in Polish banks

\begin{tabular}{|c|c|}
\hline Bank & Application functions \\
\hline & 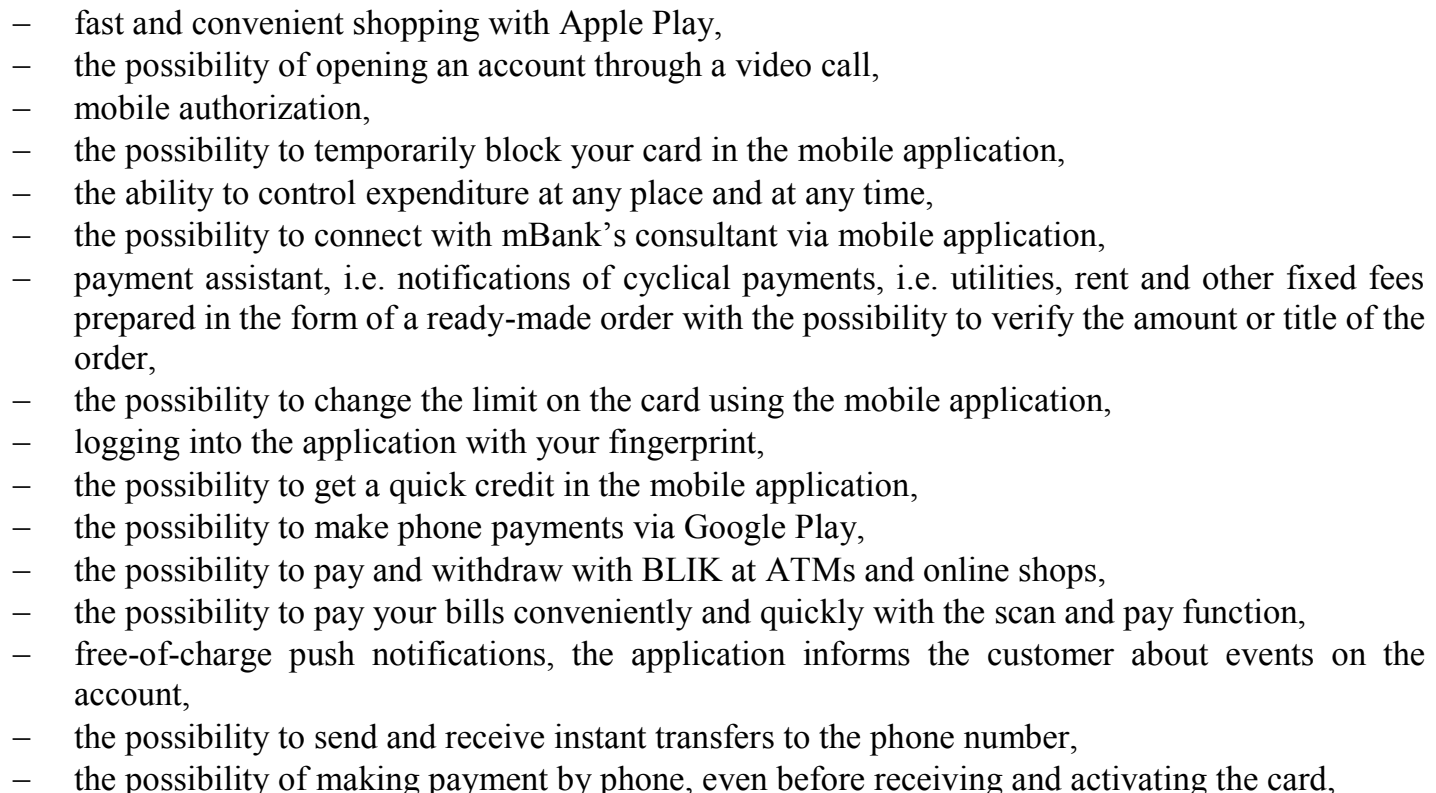 \\
\hline
\end{tabular}


Cont. table 4.

\begin{tabular}{|c|c|}
\hline & 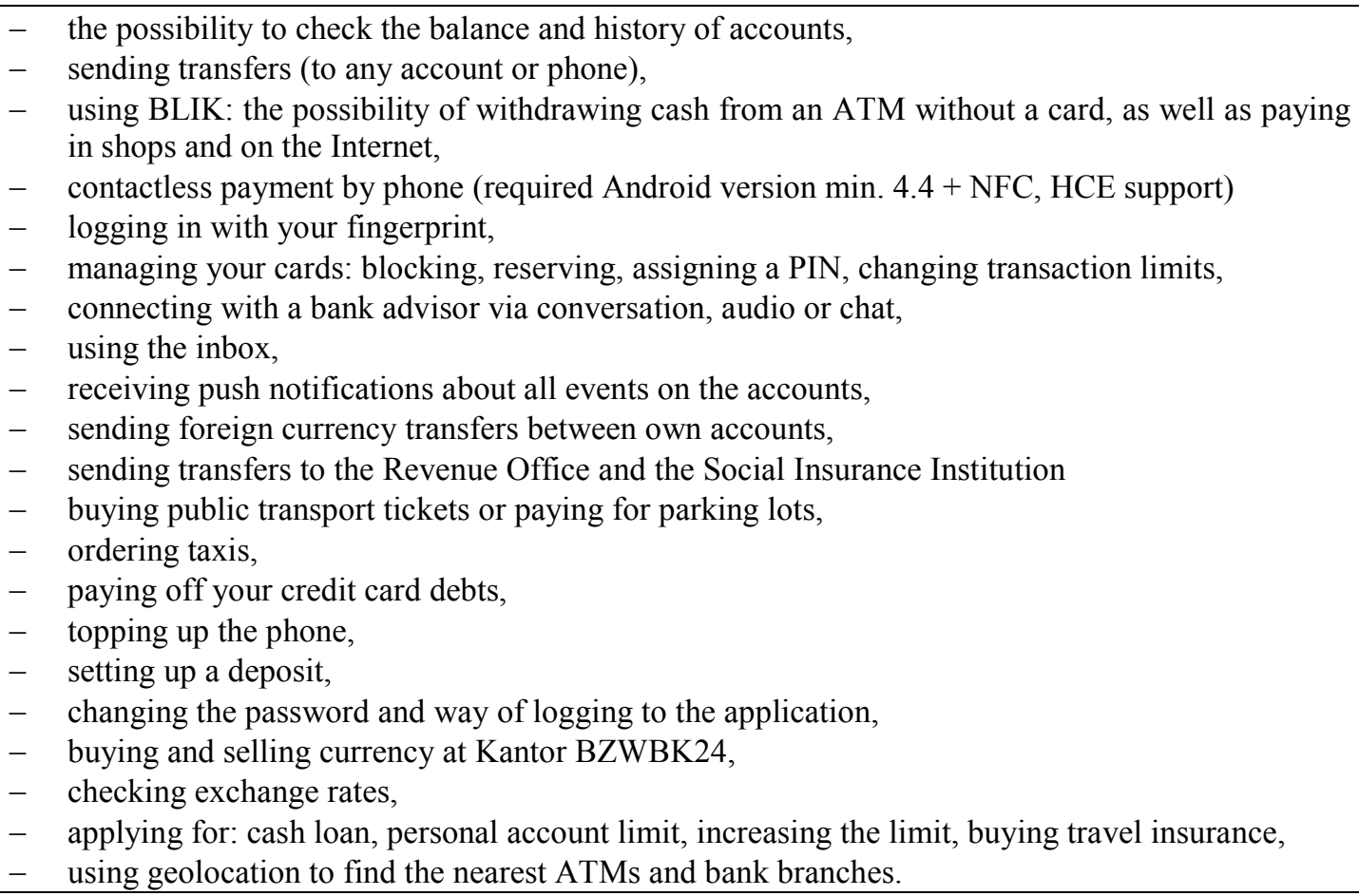 \\
\hline & 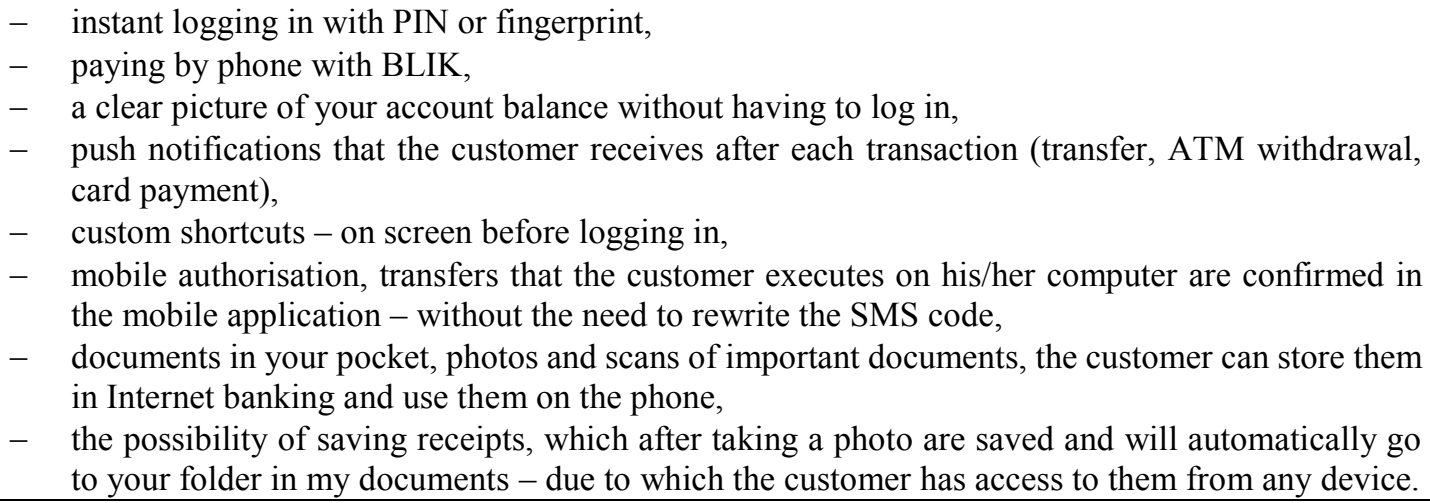 \\
\hline & 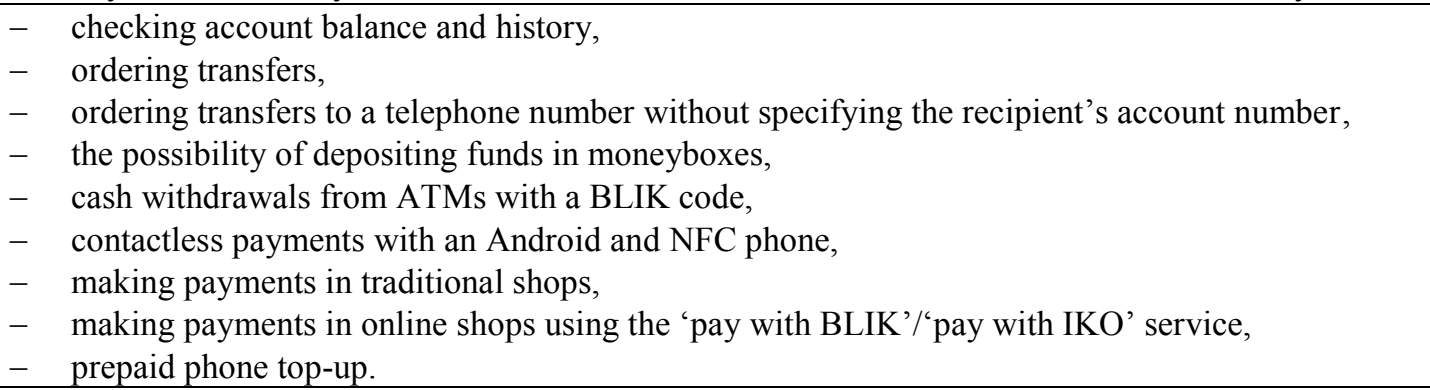 \\
\hline & $\begin{array}{l}\text { - the possibility to pay and withdraw money from ATMs with BLIK logo, } \\
\text { - } \\
\text { modern way of paying with PeoPay mobile banking or Mastercard of Bank Pekao S.A. on Apple } \\
\text { devices, } \\
\text { - the possibility of logging in with a fingerprint as well as the possibility of authorising transfers } \\
\text { and making payments in the shop (up to the amount of PLN 200), } \\
\text { - the possibility of making payments abroad by phone immediately in a given currency. } \\
\text { The application recognizes the currency of the transaction and collects money from the foreign } \\
\text { currency account (EUR, USD, GBP, CHF), } \\
\text { - } \\
\text { the possibility to pay for online purchases immediately on the phone without the need to log in to } \\
\text { Internet banking. }\end{array}$ \\
\hline
\end{tabular}


Cont. table 4.

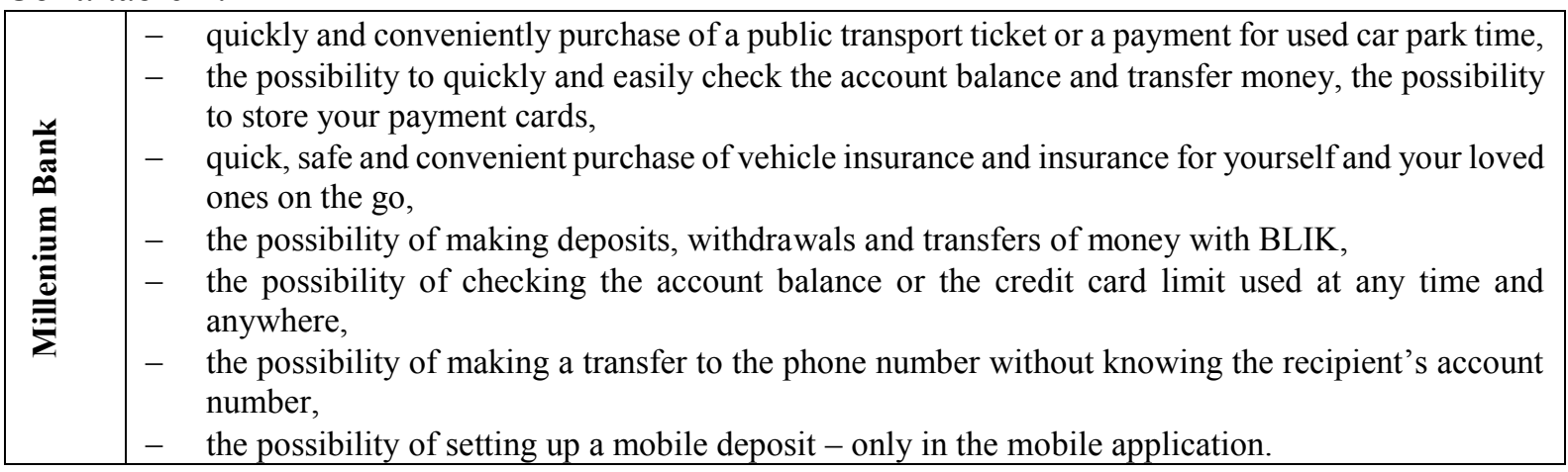

Note: www.mbank.pl; www.bzwbk.pl/; www.pekao.com.pl; www.pkobp.pl/; www.ingbank.pl, www.bankmillennium.pl (29.06.2018).

It should be stressed that the banks' activities in the area of mobile applications are highly competitive, as they see them as an important source of gaining potential customers. However, they also see the need for cooperation in this area, which was confirmed by the establishment of the Polish Payment System - BLIK. This system was launched by six banks: Alior Bank, Millennium Bank, Bank Zachodni WBK, ING Bank Śląski, mBank and PKO BP. It was created on the basis of IKO mobile payments, initially available to PKO Bank Polski. In practice, BLIK is a six-digit code displayed by the bank's mobile application, which can be used to authorise transactions or withdrawals from an ATM, exactly as if we were paying by card. Currently, we have 12 banks using BLIK, in addition to the founding banks. They include: Getin Bank, BGŻ BNP Paribas, Raiffeisen Polbank, Inteligo, Orange Finanse and T-Mobile Usługi Finansowe.

\section{Mobile banking on the Polish banking market}

According to Netb@nk reports, data from PRNews or Cashless.pl, mobile banking services are becoming more and more popular every year. Observing the way the number of its users has been changing in recent years, one can say that despite the fact that Internet banking still has many supporters, mobile banking, thanks to its innovation, is becoming a real threat to it. 


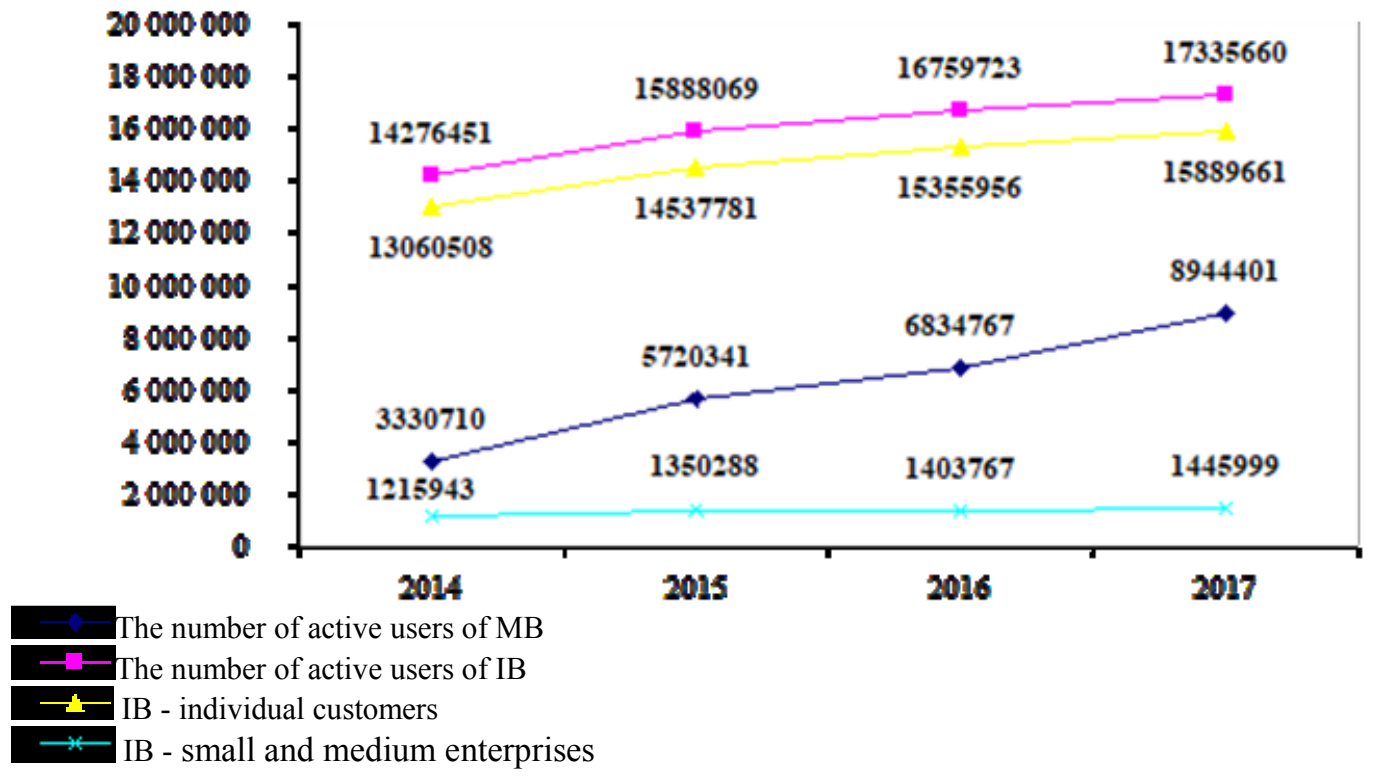

Figure 1. Number of active users of mobile banking and Internet banking. Copyright by: https://zbp.pl/raporty/raport-netb-nk; https://prnews.pl/raporty/bankowosc-mobilna (30.06.2018).

Figure 1 presents the number of active users of Internet and mobile banking, i.e. those who $\log$ in at least once a month. The data presented here clearly show that throughout the entire analysed period, both the number of active users of Internet and mobile banking increased successively from year to year. At the end of 2015, there were 32.84 million users who could use Internet banking services, of which 30.5 million were individual customers and the remaining 2.34 million were small and medium-sized enterprises. However, when looking at the activity of individual user groups this year in comparison to 2014, it can be concluded that in the case of active individual customers there was an increase in their number by almost $1.5 \mathrm{mln}$ (i.e. by $11.31 \%$ ). On the other hand, the number of active SME Internet banking users increased by nearly 135 thousand (i.e. by $11.05 \%$ ) as compared to 2014 . In the next year covered by the analysis -2016 , the number of individual customers with agreements providing access to Internet banking services amounted to 33.17 million, while the number of active individual customers of Internet banking increased that year by over 818 thousand as compared to the previous year (i.e. by $5.63 \%$ ). Whereas, the number of small and medium-sized enterprise customers who have access to Internet banking services at the end of 2016 was over $2.35 \mathrm{mln}$. Thus, an increase of nearly 53 thousand (3.96\%) was recorded compared to the previous year. The data for 2017 also confirm an increase in the number of individual customers with agreements enabling access to Internet banking services to $35.5 \mathrm{mln}$. Among them the number of active individual customers of Internet banking services increased by over 533 thousand (i.e. $3.48 \%$ ) compared to the previous year. The number of customers from the small and medium-sized enterprise sector having the possibility to use Internet banking services increased by over 42 thousand (3.01\%) compared to the previous year 2016 . 
It should be remembered that in addition to Internet banking, bank customers also have mobile banking at their disposal. These are mainly customers who use standard transaction systems in their mobile phones or tablets. The analysis of the data presented in Figure 1 shows that at the end of 2015 the number of active mobile banking users was over $5.7 \mathrm{mln}$. Thus, as of December 2014, there are 2.3 mln more customers who use the bank on mobile devices. In 2016, the number of active mobile banking users was already $6.8 \mathrm{mln}$, i.e. $1.1 \mathrm{mln}$ more than the year before. At the end of 2017, mobile banking services were already used by nearly $9 \mathrm{mln}$ users. Compared to the data presented the year before, this was an increase of $2.1 \mathrm{mln}$. As could be seen, the highest growth of the analysed values was recorded in 2015, i.e. an increase of 2,389,631 (71.7\% y/y) and in 2017 - an increase of 2,109,633 (30.8\% y/y). figure 2 shows how the number of users actively using mobile banking services in banks that are leaders in this respect was shaped.

Since 2015, the leader in this area is PKO BP S.A. bank, which had $2.2 \mathrm{mln}$ mobile banking users in 2017. It was also the bank with the largest number of users (605 thousand). The second place was taken by mBank with $1.6 \mathrm{mln}$ users (compared to 2016, it gained more than 413 thousand users), and the third place was taken by ING Bank Śląski with 1.4 mln users (an increase by 280 thousand $y / y$ ).

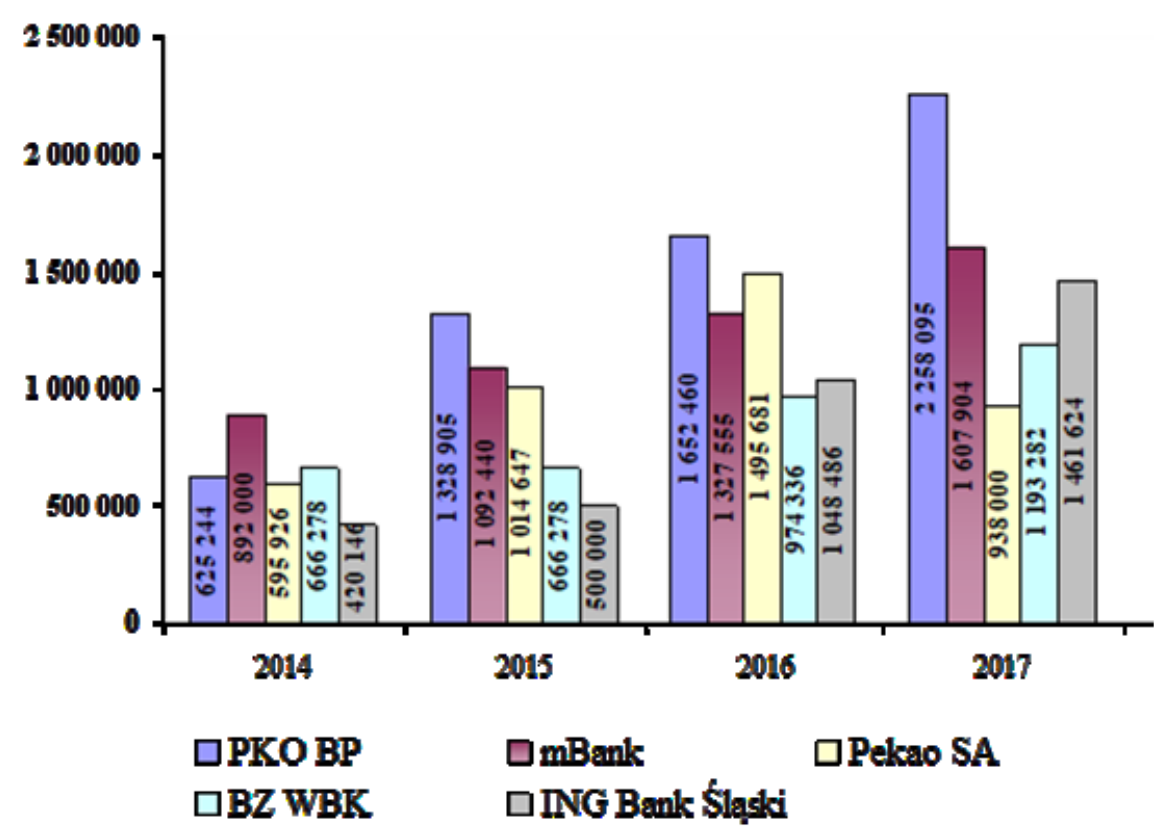

Note: PRNews.pl report: Mobile banking market - Q4 2015; PRNews.pl report: Mobile banking market Q4 2016; PRNews.pl report: Mobile banking market - Q4 2017. Copyright by www.prnews.pl

Figure 2. The number of mobile banking users who log in to a bank at least once a month from a mobile device in selected banks.

As we use mobile phones more and more often, and most of us cannot even function without them, it is also worth noting the number of active users of the mobile application for a mobile phone, as presented in figure 3 . 


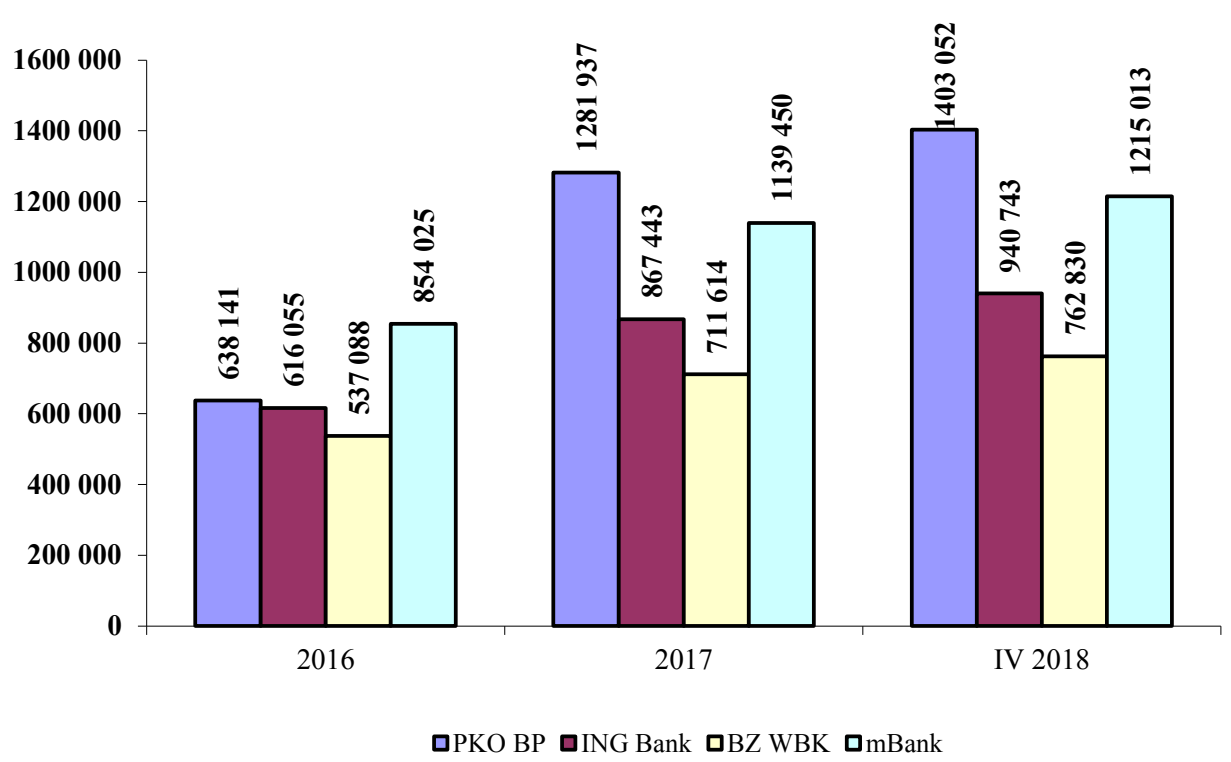

Note: PRNews.pl report: Mobile banking market - Q4 2015; PRNews.pl report: Mobile banking market Q4 2016; PRNews.pl report: Mobile banking market - Q4 2017. Copyright by www.prnews.pl

Figure 3. Number of users of the mobile application for a mobile phone in selected banks.

It should be emphasized that due to the lack of detailed data on the use of mobile applications for mobile phones by customers, the comparison covered the years 2016-17 and the first quarter of 2018. Moreover, Pekao S.A. was not included in this analysis.

According to the presented data, PKO BP S.A. has the largest number of users having mobile applications for mobile phones. Currently, there are 1,403,052 of them, the second in this respect is mBank with 1,215,013 users and the third place is taken by ING Bank with 940,743 users. Additionally, comparing data from charts 2 and 3, it can be concluded that in the surveyed banks the difference between the number of people logging inn from mobile devices (in total) and the number of application users is significant.

It is also worth noting that banks' customers carry out more and more financial transactions (mainly transfers, direct debits, loan repayments or BLIK transactions) using applications available on the market. With their help, customers made a total of $44 \mathrm{mln}$ financial transactions in 2017, which was $24 \mathrm{mln}$ more than in 2016, i.e. by 85\%. According to data as of March 2018, there were over $50 \mathrm{mln}$ of them. This represents an increase of $5.7 \mathrm{mln}$ compared to the previous quarter, and to Q1 2017, by $21.5 \mathrm{mln}$. Additionally, it should be emphasized that by 2016 there were more and more people who made mobile deposits. However, since 2017, their number has been decreasing. Undoubtedly, this may be due to the fact that the interest rate on mobile deposits is not so competitive anymore (it has recently dropped to standard levels). Initially, mobile deposits had much higher interest rates as banks encouraged customers with high rates to get used to mobile banking. Currently, this is not necessary because mobile banking has more and more followers.

In conclusion, there are several reasons for such a high growth of mobile banking users. Undoubtedly, the first and most important was the technical development that has taken place in recent years, which is mainly related to the popularisation of smartphones, as well as 
a significant drop in prices of calls and Internet access from mobile devices. It is also worth noting that the rapid technological development meant that mobile applications could be operated not only by very expensive mobile devices, which allowed banks to reach a much wider group of customers.

\section{Summary}

The main drivers of the development of mobile banking in recent years have been significant advance in information and communication technologies, as well as customer requirements for payments made. The large number of emerging mobile payment services, improved functionality and the popularization of smartphones and tablets, combined with a decrease in data transfer costs in mobile networks, growing competition in this area and a continuous increase in the number of users - all these factors indicate the potential of this sector.

More and more devices are appearing on the market, which combine the features of a mobile computer and a tablet. Today, some mobile applications already offer more than desktop versions of transaction systems. Therefore, the difference between a mobile banking user and a customer using Internet banking is slowly narrowing. However, regardless of the type of banking (mobile or Internet), its success and development is largely determined by customers' preferences and expectations regarding transaction execution.

\section{References}

1. Bakalarczyk, S. (2006). Innowacje bankowe. Bankowość elektroniczna, bankowość inwestycyjna i inżynieria finansowa. Łódź: Wydawnictwo Politechniki Łódzkiej.

2. Błach, J. (2011). Innowacje finansowe i ich znaczenie we współczesnym systemie finansowym - identyfikacja i systematyzacja problem. e-Finanse, $n r$ 7(3), p. 19.

3. Błach, J. (2012). Koszty zastosowania innowacji finansowych w działalności przedsiębiorstw - identyfikacja problemu. Annales, VOL. XLVI, 4. Lublin: Wydawnictwo UMCS.

4. Boczoń, W. (2018.06.30). Najlepsze bankowe aplikacje mobilne - marzec 2018. Retrived from https://www.bankier.pl/wiadomosc/Najlepsze-bankowe-aplikacje-mobilne-marzec2018-7577114.html.

5. Dolińska, M. (2010). Innowacje w gospodarce opartej na wiedzy. Warszawa. PWE. 
6. Frame, W.S., White, L.J. Empirical Studies of Financial Innovation: Lots of Talk, Little Action? Working Paper, 12, Federal Reserve of Atlanta. Retrieved from http://www.ssrn.com (30.06.2018).

8. Llewellyn, D.T. (2009). Financial Innovation and the Economics of Banking and the Financial System. In: L. Anderloni, D.T. Llewellyn, R.H. Schmidt, E. Elgar (Eds.), Financial Innovation in Retail and Corporate Banking. Cheltenham.

9. Marcinkowska, M. (2012). Innowacje finansowe w bankach. In: B. Mikołajczyk, Innowacyjność w systemie bankowym. Acta Universitatis Lodziensis. Folia Oeconomica, 266. Łódź, Wydawnictwo Uniwersytetu Łódzkiego.

11. Niczyporuk, P., Talecka, A. (2011). Bankowość. Podstawowe zagadnienia. Temida 2. Białystok: Wydawnictwo Stowarzyszenia Absolwentów Wydziału Prawa Uniwersytetu w Białymstoku.

14. Stachera-Włodarczyk, S. (2015). Rola innowacji finansowych w działalności banków komercyjnych. Zeszyty Naukowe Politechniki Częstochowskiej, Zarządzanie, Nr 19. Częstochowa.

16. www.zbp.pl.

18. www.PRNews.pl. 